\title{
Animal Phobia
}

National Cancer Institute

\section{Source}

National Cancer Institute. Animal Phobia. NCI Thesaurus. Code C35273.

An overwhelming, irrational, and persistent fear of animals. 